\title{
Endocrine Combination Therapy for Prostate and Metastatic Breast Cancer in a Male Patient
}

\author{
Anne K. Baumgärtner Andreas C. Schnelzer Nadia Harbeck Marion Kiechle \\ Stephanie Pildner von Steinburg \\ Frauenklinik und Poliklinik der TU München, Germany
}

\author{
Key Words \\ Breast cancer, male - Prostate cancer . \\ Prostate-specific antigen . PSA · Endocrine therapy
}

\section{Summary}

Background: Breast cancer in men is rare and requires therapy concepts including health considerations different from those in female patients. Case Report: We report on a 64-year-old male patient with metastatic breast cancer in the lung and cervical lymph nodes. Upon metastasis, initial adjuvant endocrine therapy with tamoxifen was changed to anastrozole. After 1 year of treatment, the patient was found to have rising prostatespecific antigen (PSA) levels, and diagnostic workup confirmed the diagnosis of early prostate cancer. Because of simultaneous progressive disease of metastatic breast cancer, chemotherapy with 6 cycles of docetaxel was administered resulting in a partial remission of both tumor types. The patient is currently treated with an endocrine combination therapy of fulvestrant, goserelin, and bicalutamide. $\mathrm{He}$ is in good clinical condition, and tumor markers for both tumor types are stable. Conclusion: Elevated PSA levels under therapy with aromatase inhibitors have been described in individual cases but always warrant a careful diagnostic workup to exclude prostate cancer as an important differential diagnosis. Genetic counseling has to be taken into consideration in the case of male breast cancer as well as in the case of coincidence of different tumor types, such as breast and prostate cancer, due to the possibility of e.g. BRCA mutations in these patients.

\section{Schlüsselwörter}

Brustkrebs beim Mann - Prostatakarzinom .

Prostataspezifisches Antigen - PSA - Endokrine Therapie

\section{Zusammenfassung}

Hintergrund: Brustkrebs beim Mann ist eine seltene Erkrankung, die vom behandelnden Arzt eine andere Herangehensweise erfordert als bei der weiblichen Patientin und andere Differentialdiagnosen einschließen muss. Fallbericht: Wir berichten über einen 64-jährigen Patienten mit Mammakarzinom, der unter Tamoxifen eine lymphatische und pulmonale Metastasierung entwickelte. Ein Jahr nach Umstellung der endokrinen Therapie auf Anastrozol fielen steigende PSA-Werte auf. Die Diagnostik ergab ein frühes Prostatakarzinom. Aufgrund der progredienten Mammakarzinomerkrankung wurde eine Chemotherapie mit Docetaxel durchgeführt, welche zur partiellen Remission beider Tumorentitäten führte. Aktuell ist der Patient unter einer endokrinen Dreierkombination aus Fulvestrant, Goserelin und Bicalutamid praktisch beschwerdefrei. Die Tumormarker beider Karzinome weisen im Verlauf stabile Werte auf. Zusammenfassung: Steigende PSA-Werte unter Therapie mit Aromatasehemmern sind zwar im Einzelfall beschrieben, müssen jedoch immer eine sorgfältige diagnostische Abklärung nach sich ziehen, um ein simultanes Prostatakarzinom auszuschließen. Außerdem sollte beim Auftreten eines Mammakarzinoms beim Mann wie auch beim Vorliegen mehrerer Tumorentitäten wie Mamma- und Prostatakarzinom den Patienten eine genetische Beratung empfohlen werden, da die Möglichkeit einer Genmutation, z.B. in einem der BRCA-Gene, besteht. 


\section{Introduction}

Male breast cancer is a rare disease with an annual prevalence of 1 in 100,000 [1]. Contributing etiologic factors are exposure to radiation, hyperestrogenism (from external sources or due to endogenous diseases like liver cirrhosis or Klinefelter's syndrome) or hereditary factors [2,3]. Due to the rare occurrence of breast cancer in men, there is a substantial lack of clinical trials to evaluate optimal treatment options and derive evidence-based guidelines. Thus, our understanding of the disease in male patients and our clinical approach are in fact derived from trials and experience in female breast cancer patients.

\section{Case Report}

We report on a 62-year-old male patient who was diagnosed with invasive ductal breast cancer in 2002. The tumor stage was pT2 pN1biii (12/13) M0 $\mathrm{G} 3$, estrogen receptor (ER)- and progesterone receptor ( $\mathrm{PgR}$ )-positive, Her2/neu-negative. The patient underwent mastectomy and axillary lymph node dissection, received 6 courses of adjuvant FEC (fluorouracil, epirubicin, cyclophosphamide) chemotherapy $\left(500 / 100 / 500 \mathrm{mg} / \mathrm{m}^{2} \mathrm{q} 21 \mathrm{~d}\right)$ and subsequent loco-regional radiation therapy, and was then put on adjuvant tamoxifen $20 \mathrm{mg}$ daily. In 2003, he presented to our hospital for cosmetic correction of his mastectomy scar. Preoperative routine chest X-ray showed a pulmonary mass suspicious of metastasis; all other staging examinations were normal and the patient was in excellent clinical condition. Endocrine therapy was therefore changed to anastrozole $1 \mathrm{mg}$ daily. At the same time, rising prostate-specific antigen (PSA) levels were detected during the patient's annual screening tests. Literature research and a query at the medical scientific department of AstraZeneca, Wedel, Germany, yielded evidence of 2 patients worldwide with elevated PSA levels under anastrozole therapy [4-6]. In 2005, a prostate biopsy was taken. It showed moderately differentiated adenocarcinoma of the prostate gland, Gleason score 5.

2 months later, the patient was admitted to the Ear, Nose and Throat (ENT) department for progressive enlargement of cervical lymph nodes. A diagnostic extirpation was performed, and histology revealed metastasis of invasive ductal breast cancer, hormone receptor-positive, Her2/neu-negative. Computed tomography (CT) scan of the chest showed progressive pulmonary metastatic disease. The patient's treatment options were discussed at our multidisciplinary tumor conference, and we finally opted for chemotherapy with docetaxel $100 \mathrm{mg} / \mathrm{m}^{2} \mathrm{q} 21 \mathrm{~d}$, a therapy regimen that is effective in both tumor types. After 3 chemotherapy cycles, partial remission was achieved, and a total of 6 courses yielded further consolidation of disease. The challenge now was to tailor an effective endocrine therapy encompassing both breast and prostate cancer with as little side effects and drug interactions as possible. The patient was put on a triple combination therapy of fulvestrant (Faslodex ${ }^{\mathrm{TM}}$, AstraZeneca, $250 \mathrm{mg}$ q28d i.m.), goserelin (Zoladex ${ }^{\mathrm{TM}}$, AstraZeneca, $3.6 \mathrm{mg}$ q28d s.c.), and bicalutamide (Casodex $^{\mathrm{TM}}$, AstraZeneca, $50 \mathrm{mg}$ daily p.o.). The patient consented after careful and thorough information regarding the limited evidence basis for this treatment. Since the beginning of therapy 6 months ago, the patient is in excellent clinical condition, only suffering from mild dyspnea on exertion and hot flushes. The tumor marker PSA is within normal limits $(<0.10 \mathrm{ng} / \mathrm{ml})$, and CA $15-3$ is slightly elevated on a stable level $(27 \mathrm{U} / \mathrm{ml})$.

\section{Discussion}

$90 \%$ of male breast cancers are hormone receptor-positive [1, 7]. Therefore, endocrine therapy has been a hallmark of breast cancer therapy in men both in the adjuvant and in the advanced setting. Adjuvant tamoxifen has been shown to improve disease-free and overall survival $[8,1]$. However, there is no clear data for optimal duration of treatment. Aromatase inhibitors have not been systematically studied as adjuvant therapy for male patients, and their role in the advanced setting remains controversial [9-12]. Furthermore, there is no large-scale experience with the anti-estrogen fulvestrant in male patients [13]. Carcinoma of the prostate gland is another hormone-related cancer, with the androgen receptor being expressed in nearly all prostate cancers [14].

In the case outlined above, we tailored the endocrine combination therapy as follows: The patient had progressed under both tamoxifen and anastrozole, so the next endocrine treatment option - analogous to the situation in a female patient - would be fulvestrant, an ER antagonist without agonistic effects which downregulates the ER [15]. To treat the prostate cancer, the nonsteroidal antiandrogen bicalutamide was chosen and combined with the gonadotropin-releasing hormone (GnRH) agonist goserelin to achieve optimal androgen blockade by suppressing elevated follicle-stimulating hormone (FSH) and luteinizing hormone (LH) levels [16, 17]. So far, there has been no documented experience in the literature regarding the efficacy or drug interactions of this triple therapy regimen apart from 1 case report describing the combination of an LHRH agonist and flutamide in a male patient with metastatic breast cancer [18].

Genetic susceptibility to breast cancer has been studied extensively in women, identifying multiple genes involved in breast cancer development. Probably best known and most relevant for familial breast cancer are BRCA1 and BRCA2 [19]. Autosomal dominant inheritance attributable to gene mutations in BRCA 1 or BRCA 2 is suspected in $4-40 \%$ of male breast cancer cases, and $20 \%$ of men with breast cancer are found to have first degree relatives with the same disease [1]. Prostate cancer is found with a higher prevalence among carriers of BRCA2 mutations [20, 21, 3]. Although there was no history of breast or prostate cancer in this patient's family, we recommended counseling in our specialist clinic for hereditary tumor syndromes and cancer genetics to evaluate a potential genetic background for the coincidence of the patient's 2 cancer types.

\section{Conclusion}

Given the rare occurrence of male breast cancer, optimal long-term treatment remains a challenge. Approach to the disease and patient care require taking health issues into account that are specific for the male patient. Due to the lack of large-scale prospective clinical trials, therapeutic decisions will be made in accordance to treatment of female patients and will have to be tailored individually - like in this case where 2 tumor types had to be treated simultaneously. Moreover, in the case of male breast cancer or coincidence of several different cancer types or familial breast cancer, genetic counseling should be recommended to the patient. 


\section{References}

1 Fentiman IS, Fourquet A, Hortobagyi GN: Male breast cancer. Lancet 2006;367:595-604.

2 Heinig J, Jakisch C, Rody A, Koch O, Buechter D, Schneider HP: Clinical management of breast cancer in males: a report of four cases. Eur J Obstet Gynecol Reprod Biol 2002;102:67-73.

-3 Kirchhoff T, Kauff ND, Mitra N, Nafa K, Huang H, Palmer C, Gulati T, Wadsworth E, Donat S, Robson ME, Ellis NA, Offit K: BRCA mutations and the risk of prostate cancer in Ashkenazi Jews. Clin Cancer Res 2004;10:2918-2921.

4 Santen RJ, Petroni GR, Fisch MJ, Myers CE, Theodorescu D, Cohen RB: Use of the aromatase inhibitor anastrozole in the treatment of patients with advanced prostate cancer. Cancer 2001;92 2095-2101.

5 Fachinformation Arimidex $1 \mathrm{mg}$ Filmtabletten. July 2005.

6 Reckzeh, MedWiss AstraZeneca: Personal communication, January 2005.

7 Murphy CE, Carder PJ, Lansdown MR, Speirs V: Steroid hormone receptor expression in male breast cancer. Eur J Surg Oncol 2006;32:44-47.
Goss PE, Reid C, Pintilie M: Male breast carcinoma: a review of 229 patients who presented to Princess Margaret Hospital during 40 years: 19551996. Cancer 1999;85:629-639.

9 Giordano SH, Valero V, Buzdar AU, Hortobagyi GN: Efficacy of anastrozole in male breast cancer. Am J Clin Oncol 2002;25:235-237.

10 Zabolotny BP, Zalai CV, Meterissian SH: Successful use of letrozole in male breast cancer: a case report and review of hormonal therapy for male breast cancer. J Surg Oncol 2005;90:26-30.

11 Nahleh ZA: Hormonal therapy for male breast cancer: A different approach or a different disease. Cancer Treat Rev 2006;32:101-105.

12 Hayes T: Pharmacotherapy for male breast cancer. Expert Opin Pharmacother 2002;3:701-708.

3 Volm MD: Male breast cancer. Curr Treat Options Oncol 2003;4:159-164.

14 Culig Z: Role of the androgen receptor axis in prostate cancer. Urology 2003;62(suppl 5A):21-26.

15 Piccart M, Parker LM, Pritchard KI: Oestrogen receptor downregulation: an opportunity for extending the window of endocrine therapy in advanced breast cancer. Ann Oncol 2003;14:10171025 .
16 Karamanakos P, Mitsiades CS, Lembessis P, Kontos M, Trafalis D, Koutsilieris M: Male breast adenocarcinoma in a prostate cancer patient following prolonged anti-androgen monotherapy. Anticancer Res 2004;24:1077-1081.

17 Rau KM, Kang HY, Cha TL, Miller SA, Hung MC: The mechanisms and managements of hormonetherapy resistance in breast and prostate cancers. Endocr Relat Cancer 2005;12:511-532.

18 Labrie F, Dupont A, Belanger A, Lacourciere Y, Beland L, Cusan L, Lachance R: Complete response to combination therapy with an LHRH agonist and flutamide in metastatic male breast cancer: a case report. Clin Invest Med 1990;13:275278 .

19 Thompson D, Easton D: The gentic epidemiology of breast cancer genes. J Mammary Gland Biol Neoplasia 2004;9:221-236.

20 Dong JT: Prevalent mutations in prostate cancer. J Cell Biochem 2006;97:433-447.

21 Horsburgh S, Matthew A, Bristow R, Trachtenberg J: Male BRCA1 and BRCA2 mutation carriers: a pilot study investigating medical characteristics of patients participating in a prostate cancer prevention clinic. Prostate 2005;65:124-129. 